вопросов. Данное обстоятельство обусловит новые ракурсы в рассмотрении сложного вопроса. Для изменения традиционной схемы можно приготовить заранее 2-3 набора карточек с вопросами. При обсуждении родители выбирают карточку (не видя ее вопроса) и затем отвечают на него, продолжая мысль предыдущего выступающего. Всего может получиться 21 комбинация вопросов.

Таким образом, применение разнообразных форм проведения родительских собраний будет способствовать:

- повышению интереса родителей к педагогическим вопросам;

- привлечению внимания к проблемам школы и класса;

- росту размышлений о правильности своих поступков в отношении детей;

- возрастание заинтересованности в дискуссиях;

- развитию умений решать сложные ситуации в детско-родительских отношениях.

1. Юсуфбекова, Р.Н. Общие основы педагогической инноватики. Опыт разра-ботки теории инновационных процессов в образовании / Р.Н. Юсуфбекова. - М.: Педагогическое общество, 1991. - $91 \mathrm{c}$.

2. Х Хуторской, А.В. Педагогическая инноватика / А.В. Хуторской. - М.: Ака-демия, 2010. - С. 28-29.

3. Гавриловец, К.В. Гуманистическое воспитание в школе: пособие для ди-ректоров школ, учителей, кл. рук./ К.В. Гавриловец. - Минск: Полымя, 2000. - 128 с.

\title{
Chemerilova I.A. \\ Psychological and pedagogical difficulties of parents raising children with disabilities in terms of inclusive practice
}

Chuvash state University named I. N. Ulyanov (Russia, Cheboksary)

doi: $10.18411 / \mathrm{lj}-07-2021-160$

\section{Abstract}

The paper presents experimental survey of parents of children with disabilities.

The aim of this study was to identify psychological and pedagogical difficulties of parents of children with disabilities in terms of inclusive practices. Implementation of research tasks was achieved on the basis of methods of psychological diagnostics. The study showed that parents raising children with disabilities face many psychological and pedagogical difficulties. These difficulties hinder the development of parental competencies that are necessary for full child's involvement in an inclusive process.

Keywords: inclusive practice, family support, psychological and pedagogical difficulties of parents, children with disabilities.

\section{Аннотация}

В работе представлены экспериментальные данные обследования родителей, воспитывающих детей с ограниченными возможностями здоровья.

Целью данного исследования стало выявление психолого-педагогических затруднений родителей, воспитывающих детей с ограниченными возможностями здоровья, в условиях инклюзивной практики. Реализация исследовательских задач была достигнута на основе методов психологической диагностики. Исследование показало, что родители, воспитывающие детей с ограниченными возможностями здоровья, сталкиваются с рядом психолого-педагогических затруднений, сдерживающих 
развитие родительских компетенций, необходимых для полноценного включения ребенка в инклюзивный процесс.

Ключевые слова: инклюзивная практика, сопровождение семьи, психологопедагогические затруднения родителей, дети с ограниченными возможностями здоровья.

\section{Introduction}

The relevance of the study is justified by the fact that the modern situation in education requires the active involvement of parents raising children with disabilities in inclusive education. The analysis of scientific publications and state practice showed that many parents have difficulties that are not able to cope with on their own. Many parents themselves are in need of complex socio-psychological and pedagogical help and support.

Domestic researchers (A. A. Wenger, G. L. Profitable, E. M. Leonhard, etc.) have concluded that an important task of the rehabilitation process of children with disabilities is to promote appropriate competencies of parents.

In the background of the development of inclusive processes the role of parents in interaction with the school is changing. Their opinion sometimes becomes the most important in making administrative decisions. A new ideology of cooperation between families raising children with disabilities and teachers requires different relationships aimed at recognizing the competence of the concerned person (parents). It always requires all family authority in defining the educational requirements and life strategies of the child. The parents' need in providing their children the opportunity to live and learn together with their peers is an essential resource for the inclusion development.

The ability to organize a productive dialogue with parents, to involve their participation and cooperation, to discuss conditions of a child's education are important tasks of the school community since the position of parents in the inclusive education will become increasingly independent and active. Therefore, the development of scientific approaches (methodological, practical) to organize support for families with children with disabilities is actual nowadays [1].

\section{Problem Statement}

The scientific publications and practice showed that many parents have difficulties that they are not able to cope with on their own.

Many parents themselves need comprehensive socio-psychological and pedagogical assistance and support.

It is important to learn actual problems related to the support of families raising children with disabilities to improve inclusive process. The assistance to the parents in the formation the appropriate competency is key to the successful solution of children's rehabilitation problems.

\section{Research Questions}

The problem of the study of the competence of parents raising children with disabilities, and identification of the terms of their formation need further development.

In the context of our study under the competence of parents raising children with disabilities, we understand the set of their acquired knowledge, abilities, skills, experience and relationships to successfully participate in the solution of tasks of the rehabilitation process of the child's social adaptation and integration into society.

As a basis for the formation of these competencies we can consider: 1) parental responsibility for creating conditions for harmonization family relations; 2) the establishment and keeping humane relationships with the child; 3) compliance of education of children with disabilities to their individual and age features of personality; 4) commitment of parents to work closely with specialists for successful social adaptation of the child; 5) focus education on developing children's social skills, social activity, initiative.

In our opinion the components of the medico social competence are the formation of parents' adequate holistic view on the violations of the child's psychophysical development and on the education and socialization; knowledge of medical indications and 
contraindications, of the first aid methods, of social guarantees for the child and of the possibilities of social assistance.

To the components of socio-psychological competence we include: active social position of the parents (parent), expressed in the desire to visit cultural events with the child to stimulate his communication with peers, to be creative; the ability to maintain a stable emotional state, a favorable psychological background of family communication; formation of communication skills, the parent-child activities.

To the psycho-pedagogical competences we include: a sense of self-confidence, adequate self-esteem, the motivation to the adoption of the child's defect, the position of unconditional acceptance of your child; mastering the methods and techniques of work with the child based on individual educational and rehabilitation programs; desire to enlarge the emotional world of their child, the ability to prevent and correct fears, aggression, insecurity and other negative states.

\section{Purpose of the Study}

The purpose of the study is to identify psychological and pedagogical difficulties of parents of children with disabilities in terms of inclusive practices.

\section{Research Methods}

Implementation of the research tasks was achieved through such method as: survey, questionnaire, diagnostic methods: a parental relationship questionnaire (A. J. Varga and V. V. Stolin), Personal scale of anxiety (J. Taylor, adaptation of T. A. nemcina), the Technique of neuro-psychic tension diagnostic (T. A. Nemchin).

\section{Findings}

The study revealed the following problems:

1) low level of parents' educational competence; the prevalence of such parenting as: hyperopia (35\%), authoritarian parenting style (28\%), emotional rejection of the child (20\%).

2) weak skills of interaction with children. Only $15 \%$ of respondents said that they regularly cooperate with children; and $42 \%$ admitted that they often face with powerlessness because of the inability to resolve conflicts with their child constructively.

3) weak opportunities to expand the social space of the studied families. Only $14 \%$ of parents visit different cultural events with their children.

4) low parents' satisfaction with the expert consultations. $32 \%$ of respondents answered that they have positive experiences with the experts support.

5) difficulties with implementing communications between family members, because $27 \%$ of the respondents said that there are regular family conflicts over the situation with the child.

6) According to the survey, $62.5 \%$ of parents face with stress, tension because of problems with their child. $25 \%$ have these problems often, and $12.5 \%$ have them quite often.

7) Half of the surveyed revealed a high level of anxiety. $28 \%$ have average level with a tendency to high, $22 \%$ of respondents have average level with a tendency to low. A significant part of these families are dysfunctional families which are related to the group of risk.

The study found that most families $(64 \%)$ have excessive and $32 \%$ have moderate mental stress. $65 \%$ of parents admitted that they often face with destructive emotions: guilt, heartache, despair, fear, depression etc.

\section{Conclusion}

The study showed that parents raising children with disabilities face many psychological and pedagogical difficulties. These difficulties hinder the development of parental competencies that are necessary for full child's involvement in an inclusive process.

1) Low level of educational competence;

2) aborted skills with children;

3) weak opportunities for the expansion of social space; 
4) difficulties in implementing communication in the family;

5) problems with the formation positive life adaptation.

In our opinion the most effective remedy of the identified difficulties is the multipurpose support of families raising children with disabilities in terms of inclusive practices. An important position in theory support is the fact that the problem of child's development in each case can be child himself, teachers, parents and child's entourage.

Comprehensive support for families raising children with disabilities is activity aimed at actualization of the correctional resources of the family, ensuring the efficiency of its functioning, especially in times of crises related to the upbringing and development of the child. Parents need this organized help of various experts for the decision of tasks of the rehabilitation process [2].

It is important to create an individual support program in educational organization for each family.

A differentiated approach to the process of support is the most appropriate. These approach cover such parameters as: the severity of the child's disease, gender features of the process, psychological and pedagogical culture level of parents, the nature of the difficulties, the formation of parental competence, adaptive capacity of the family.

It is necessary to solve this problem fully in a particular town, district and village. It is very important to develop a clear implementation mechanism of the interaction of various parties support. We have developed methodological guidelines for monitoring studies of the effectiveness of this process. A professional approach, mobility, transparency, individualization, feedback are necessary requirements for its organization and implementation.

Practice and publications of the study [3-7] has shown that it is very important to unite parents of children in the informal communities, for example clubs, to coordinate interaction of parents and experts in rehabilitation; to provide methodology and software for the process; to use active and interactive methods of working with parents. All these methods can increase parental competence in questions of education of children with disabilities.

The reported study was funded by RFBR, project number 20-013-00765. ***

1. Alekhina, S. V.; Semag, M. M. (Eds.). Sozdanie i oprobatsiya modeli psikhologopedagogicheskogo soprovozshdenia incluzivnoi praktiki: metodicheskoe posobie [Creation and testing of a model of psychological and pedagogical support of inclusive practice: a methodological manual]. Moscow: Moscow State University of Psychology and Education, 2012. Available at: http://psychlib.ru/resource.php/pdf/documents/SIa-2012.pdf\#page=1.Access: June, 15, 2021.

2. Chemerilova I. A., Muradymov O. N. Problems of integrated support for parents raising children with disabilities //Identity, society, culture, and education: challenges of the XXI century: collection of scientific works. art graduates, job seekers, teachers. - Cheboksary: publishing house of the Chuvash. University press, 2016. - P. 151-155.

3. Isa SNI, Ishak I, Ab Rahman A., et al. Health and quality of life among the caregivers of children with disabilities: a review of literature. Asian J. of Psychiatry. 2016; 23:71-77.

4. Kalinina, N. V.; \& Khairudinova, R. I. Psikhologicheskiye osobennosti roditeley, vospityvayushchikh detey s ogranichennymi vozmozhnostyami zdorov'ya, integriruyemykh v inklyuzivnuyu obrazovatel'nuyu sredu [Psychological features of parents raising children with disabilities that are integrated into an inclusive educational environment]. European Social Science Journal, (2013). 2(12), 156-160. Available at:https://www.elibrary.ru/item.asp?id=21495179. Access: June, 15, 2021.

5. King, G.; Willams, L. \& Hahn Gjldberg, S. Family-oriented services in pediatricrehabilitation: a scoping review and framework to promote parent and family wellness. Child: Care, Health and Development, 2017, 43(3), 334-347. Available at: https://doi.org/10.1111/cch.12435. Access: June, 16, 2021.

6. McConnell D, Savage A, Breitkreuz R. Resilience in families raising children with disabilities and behavior problems. Res. in Developmental Disabil. 2014; 35.4: 833-848.

7. Resch JA, Mireles G, Benz MR, et al. Giving parents a voice: a qualitative study of the challenges experienced by parents of children with disabilities. Rehabilitation Psychol. 2010; 55.2:139-150. 